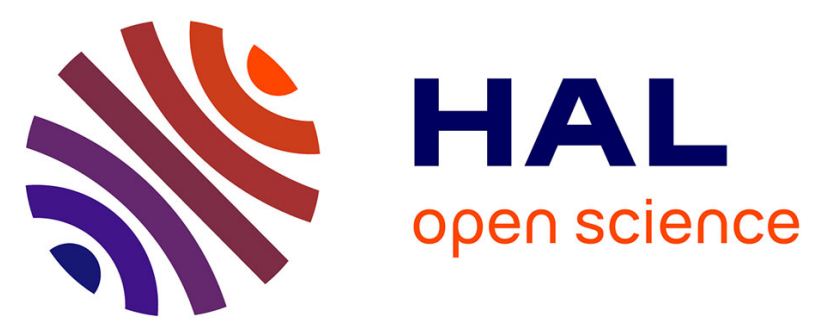

\title{
Simultaneously Electrogenerated Cycloaddition Partners for Regiospecific Inverse-Electron-Demand Diels-Alder Reactions: A Route for Polyfunctionalized 1,4-Benzoxazine Derivatives
}

Estelle Blattes, Maurice-Bernard Fleury, Martine Largeron

\section{To cite this version:}

Estelle Blattes, Maurice-Bernard Fleury, Martine Largeron. Simultaneously Electrogenerated Cycloaddition Partners for Regiospecific Inverse-Electron-Demand Diels-Alder Reactions: A Route for Polyfunctionalized 1,4-Benzoxazine Derivatives. Journal of Organic Chemistry, 2004, 69 (3), pp.882890. 10.1021/jo035614b. hal-02385054

\section{HAL Id: hal-02385054 \\ https://hal.science/hal-02385054}

Submitted on 5 Feb 2021

HAL is a multi-disciplinary open access archive for the deposit and dissemination of scientific research documents, whether they are published or not. The documents may come from teaching and research institutions in France or abroad, or from public or private research centers.
L'archive ouverte pluridisciplinaire HAL, est destinée au dépôt et à la diffusion de documents scientifiques de niveau recherche, publiés ou non, émanant des établissements d'enseignement et de recherche français ou étrangers, des laboratoires publics ou privés. 


\title{
Simultaneously Electrogenerated Cycloaddition Partners
}

\section{for Regiospecific Inverse-Electron-Demand Diels-Alder}

\author{
Reactions: a Route for Polyfunctionalized 1,4-
}

\section{Benzoxazine Derivatives.}

\author{
Estelle Blattes, Maurice-Bernard Fleury and Martine Largeron* \\ UMR 8638 CNRS - Université René Descartes, Synthèse et Structure de Molécules d'Intérêt \\ Pharmacologique, Faculté des Sciences Pharmaceutiques et Biologiques, 4 Avenue de l'Observatoire, \\ 75270 Paris Cedex 06, France.
}

Corresponding author's footnotes: phone: 3301537396 27; fax: 330144073588

E-mail: largeron@pharmacie.univ-paris5.fr

Title running head: Simultaneously electrogenerated partners for [4 + 2] cycloadditions

Abstract: A multi-step one-pot electrochemical synthesis of a variety of complex 2-alkylamino-1,4benzoxazine derivatives is described. The reactions are regiospecific and diastereospecific in the case of heterocyclic annulation. This cascade sequence, wherein both cycloaddition partners are generated in situ, at room temperature, under metal-free conditions, allows the inverse-electron-demand Diels-Alder reaction of an $o$-iminoquinone diene and a secondary alkylenamine dienophile, two chemically non accessible unstable entities. To increase the molecular diversity, a variant in which the enamine is separately prepared completes the aforementioned procedure. The extension of this reaction should be useful to generate libraries of heterocycles. 


\section{Introduction}

The Diels-Alder (DA) reaction constitutes one of the most powerful synthetic routes for the construction of six membered ring systems, ${ }^{1}$ and it has been applied to the synthesis of complex pharmaceutical and biologically active compounds. ${ }^{2}$ Since the discovery of natural Diels-Alderase enzymes, ${ }^{3}$ this reaction is no longer regarded as the exclusive domain of synthetic organic chemistry and there is currently much interest in developing enzyme-catalyzed DA reactions due to the level of stereocontrol that can be exercised. ${ }^{4}$ The most commonly utilized DA reaction is the normal DA reaction which requires an electron-poor dienophile and an electron-rich diene. In contrast, the scope and frequency of the inverse-electron-demand Diels-Alder (IEDDA) reaction are dwarfed by those of the normal DA reaction, the major limitation of the IEDDA reaction being a lack of ready accessible simple electron-deficient dienes. It is however well established that azadienes are effective aromatic dienes to participate in IEDDA reactions leading to a plethora of heterocyclic compounds. ${ }^{5}$

Recently, we showed that electrogenerated 3,4-azaquinone $\mathbf{1}_{\mathbf{o x}}$ behaved as an efficient catalyst for the autorecycling oxidation of aliphatic primary amines under metal-free conditions. ${ }^{6}$ The catalytic

Scheme 1. Catalytic oxidation of primary aliphatic amines mediated by electrogenerated 3,4 -azaquinone $\mathbf{1}_{\mathbf{o x}}$.

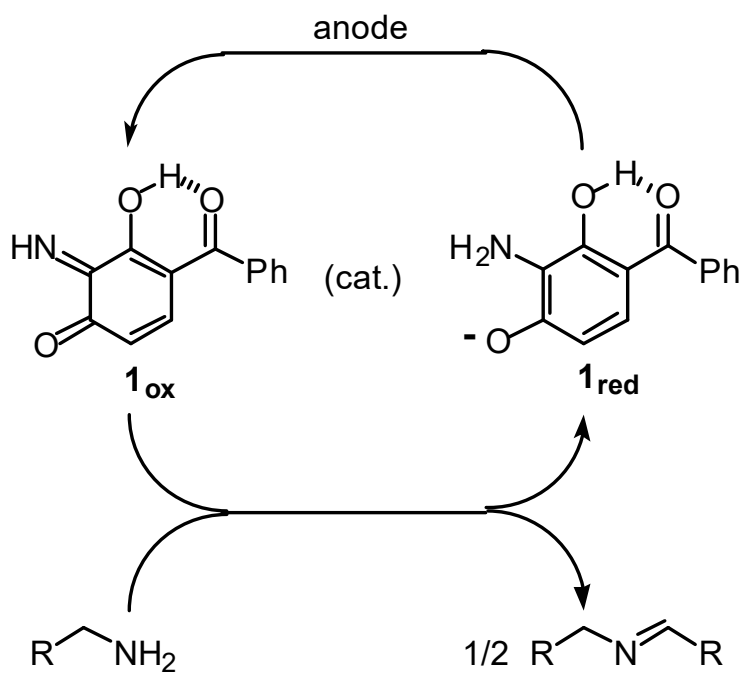


cycle produced the reduced catalyst $\mathbf{1}_{\text {red }}$ and an alkylimine as the product of amine oxidation (Scheme 1).

However, in the case of $\mathrm{R}^{1} \mathrm{R}^{2} \mathrm{CHCH}_{2} \mathrm{NH}_{2}$ amines, the catalytic process ceased after a few turnovers, as the catalyst was trapped through [4+2] cycloaddition reaction with the simultaneously electrogenerated tautomeric enamine form of the alkylimine extruded during the catalytic process (Scheme 1). This serendipitous reaction allowed the rapid and regiospecific construction of polyfunctionalized 1,4benzoxazine derivatives through a cascade transformation wherein both cycloaddition partners were generated in situ. An expedient investigation of the reaction led to a preliminary communication. ${ }^{7}$ Because the reactivity of $o$-quinone imine as an azadiene for IEDDA reactions represented uncharted terrain, though similar reactions with $o$-quinone monoimides ${ }^{8}$ and $o$-quinone monooximes ${ }^{9}$ are known, we then decided to explore further its potential for [4+2] cycloaddition reactions with variously substituted enamines. In this paper, we present a full account of the $\mathbf{1}_{\mathbf{o x}}$-mediated cascade reactions leading to the construction of complex 1,4-benzoxazine derivatives in a regiospecific manner and allowing diastereospecific heterocyclic annellation.

\section{Results and Discussion}

Optimization of the $1_{0 x}$-mediated cascade reactions. First, we have performed optimization studies of the $\mathbf{1}_{\mathbf{o x}}$-mediated cascade reactions using aminomethylcyclohexane as the amine substrate. As shown in Table 1, we found that the optimum conditions required a mercury anode, methanol as the solvent and tetraethylammonium perchlorate (TEAP) as the supporting electrolyte. 1.0 equiv of $\mathbf{1}_{\text {red }}$ and 20.0 equiv of amine substrate were an ideal reagent combination for the reaction (Table 1, entry 2). Under these conditions, the cyclic voltammogram of compound $\mathbf{1}_{\text {red }}(2 \mathrm{mM})$, in deaerated $\mathrm{MeOH}$ containing an excess of aminomethylcyclohexane $(40 \mathrm{mM})$, at a dropping mercury electrode, showed an oxidation peak Pa due to a diffusion-controlled two-electron process at - $50 \mathrm{mV}$ vs SCE, the sweep rate being 0.5 $\mathrm{V} \mathrm{s}^{-1}$. As can be seen in Figure 1, a cathodic peak Pc appeared on the reverse sweep at $-150 \mathrm{mV}$ vs SCE, illustrating the partial reversibility of the two-electron transfer that could be assigned to the 3,4aminophenol $\mathbf{1}_{\text {red }} / 3,4$-iminoquinone $\mathbf{1}_{\mathbf{o x}}$ redox couple. However, the redox potential E' ${ }^{\circ}$ could not be 
accurately evaluated under our experimental conditions, as the system ( $\mathrm{Pa}, \mathrm{Pc})$ did not fulfill all the diagnostic criteria required for a reversible process, at least when $\mathrm{v}$ was $\leq 500 \mathrm{~V} \mathrm{~s}^{-1}$ : the ratio of the

Table 1. Optimization of the $1_{\mathrm{ox}}$-mediated cascade reaction

\begin{tabular}{|c|c|c|c|c|c|c|c|}
\hline & $1_{\text {red }}$ & & $1_{\text {ox }}$ & & $\mathrm{H}$ & & $2 a$ \\
\hline Entry & Anode & Solvent & Supporting electrolyte & $\begin{array}{l}\text { Initial concentration } \\
\text { of } 1_{\text {red }}(\mathrm{mM})\end{array}$ & $\begin{array}{l}\text { Aminomethyl } \\
\text { cyclohexane } \\
(\mathrm{mM})\end{array}$ & $\mathrm{n}^{a}$ & Yield $(\%)^{b}$ \\
\hline 1 & $\mathrm{Hg}$ & $\mathrm{MeOH}$ & TEAP & 2.0 & 20.0 & 11 & 66 \\
\hline 2 & $\mathrm{Hg}$ & $\mathrm{MeOH}$ & TEAP & 2.0 & 40.0 & 16 & 77 \\
\hline 3 & $\mathrm{Hg}$ & $\mathrm{MeOH}$ & TEAP & 2.0 & 100.0 & 17 & 51 \\
\hline 4 & $\mathrm{Hg}$ & $\mathrm{MeOH}$ & TEAP & 1.0 & 40.0 & 14 & 68 \\
\hline 5 & $\mathrm{Hg}$ & $\mathrm{MeOH}$ & TEAP & 0.5 & 40.0 & 15 & 52 \\
\hline 6 & $\mathrm{Hg}$ & $\mathrm{MeOH}$ & $\mathrm{LiClO}_{4}{ }^{\mathrm{C}}$ & 2.0 & 40.0 & 12 & 76 \\
\hline 7 & $\mathrm{Hg}$ & $\mathrm{MeOH}$ & TEATFB & 2.0 & 40.0 & 15 & 56 \\
\hline 8 & $\mathrm{Hg}$ & $\mathrm{MeCN}^{d}$ & TEAP & 2.0 & 40.0 & 15 & 10 \\
\hline 9 & $\mathrm{Pt}$ & $\mathrm{MeOH}$ & TEAP & 2.0 & 40.0 & 25 & 47 \\
\hline 10 & Carbon & $\mathrm{MeOH}$ & TEAP & 2.0 & 40.0 & 15 & 10 \\
\hline
\end{tabular}

TEAP = tetraethylammonium perchlorate, TEATFB = tetraethylammonium tetrafluoroborate. $\mathrm{rt}, 8 \mathrm{~h}$.

${ }^{a}$ Total number of electrons transferred per molecule of $1_{\text {ox }} .{ }^{b}$ Yields refer to chromatographically pure isolated products. ${ }^{c}$ TEAP is preferred over $\mathrm{LiClO}_{4}$, due to the potentially explosive hazard character of the latter. ${ }^{d} \mathrm{MeCN}$ is not a suitable solvent probably because strong solvation of methanol to the azaquinone1 $\mathbf{1}_{\mathbf{x}}$ may be required to enhance the electrophilicity of the quinonoid moiety of $1_{\text {ox }}$, making it capable to participate in IEDDA reaction.

height of $\mathrm{Pa}$ over that of $\mathrm{Pc}$ never reached unity (iPc/iPa 0.8) and the value of EPa - EPc (E being the peak potential) was found to be higher than $30 \mathrm{mV}$. Note that, in the reverse sweep, a second reduction peak $\mathrm{Pc}^{\prime}$ was recorded at a more negative potential (- $1770 \mathrm{mV}$ vs SCE) due to the irreversible twoelectron reduction of the carbonyl group of the benzophenone skeleton. ${ }^{6 a}$ 
When the controlled potential of the mercury pool was fixed at $+50 \mathrm{mV}$ vs SCE, that is at a potential for which $\mathbf{1}_{\text {red }}$ could be oxidized to the iminoquinone form $\mathbf{1}_{\mathbf{o x}}$ (Figure 1), the anodic current remained unchanged for a certain time, consistent with steady state catalytic behavior.

Figure 1. Cyclic voltammogram of $\mathbf{1}_{\text {red }}(2 \mathrm{mM})$ at a dropping mercury electrode in deaerated $\mathrm{MeOH}$ containing tetraethylammonium perchlorate $(20 \mathrm{mM})$ and aminomethylcyclohexane $(40 \mathrm{mM})$. Arrowheads indicate the direction of the potential sweep; $v=0.5 \mathrm{~V} \mathrm{~s}^{-1}$. The vertical arrow indicates the initial potential point.

Accordingly, a value of 16 was found for the total number of electrons (n) transferred per molecule of $\mathbf{1}_{\text {red }}$ in the catalytic process ( 8 turnovers). These results indicated that the $\mathbf{1}_{\text {red }} / \mathbf{1}_{\mathbf{o x}}$ system

Scheme 2. Regiospecific IEDDA reaction of enamine dienophile witho-azaquinone diene $\mathbf{1}_{\mathrm{ox}}$, electrogenerated simultaneously, to give polyfunctionalized 1,4-benzoxazine derivatives.

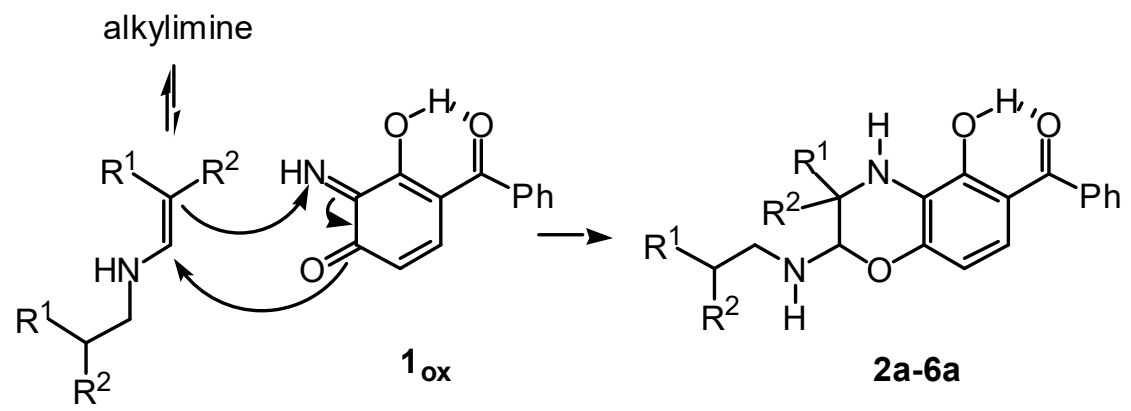


behaved as a redox mediator for the indirect electrochemical oxidation of aminomethylcyclohexane to the corresponding alkylimine (Scheme 1), according to the transamination mechanism previously reported. ${ }^{6 a}$ Further, the catalytic process ceased and close inspection of the exhaustively oxidized solution revealed that electrogenerated 3,4-azaquinone $\mathbf{1}_{\mathbf{o x}}$ was trapped with the tautomeric enamine form of the alkylimine produced during the catalytic process (Scheme 2), to give the substituted 2alkylamino-1,4-benzoxazine 2a in 77\% yield, along with 3\% of the accompanying 2-hydroxy byproduct $\mathbf{2 b}$ resulting from the conversion of $\mathbf{2 a}$ on silica gel ${ }^{10}$ (Table 2, entry 1). At this point, it should be mentioned that the workup and isolation procedures were crucial to the success of this reaction (see Experimental Section). In particular, under acidic workup conditions, the 2-alkylamino chain was removed and the 2-alkylamino-1,4-benzoxazine derivative 2a was converted to the corresponding 2hydroxy compound $\mathbf{2} \mathbf{b}$. This ease of transformation was confirmed by treatment of benzoxazine $\mathbf{2 a}$ under various acidic conditions which yielded hemiacetal $\mathbf{2 b}$ in high yields (Table 3, entries 1-4). 
Table 2. $(4+2)$ cycloaddition reaction of simultaneously electrogenerated $o$-azaquinone diene $\mathbf{1}_{\mathrm{ox}}$ and enamine dienophile ${ }^{a}$

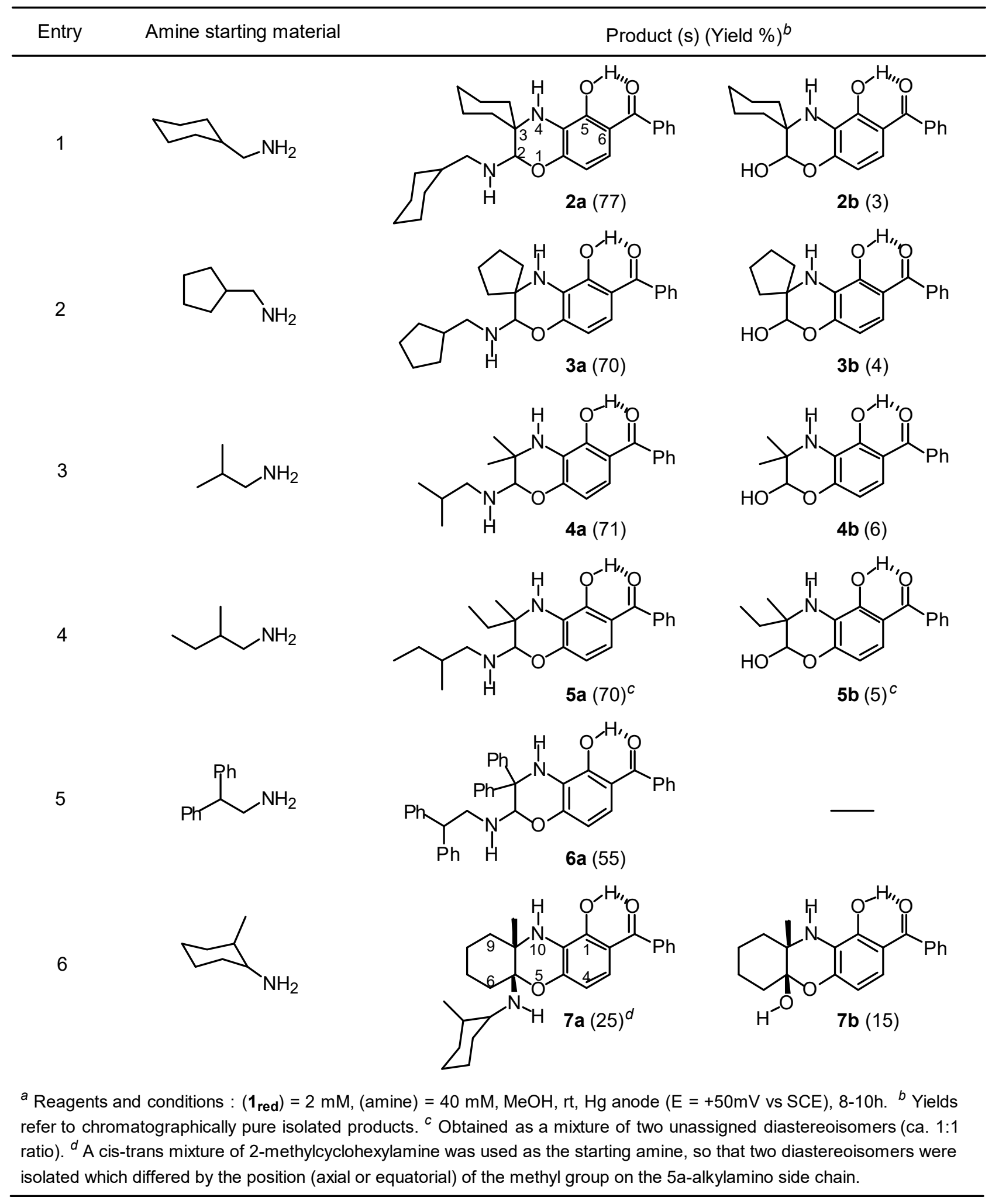


Table 3. Hydrolysis ${ }^{a}$ of 2-alkylamino-benzoxazines 2a-6a to 2-hydroxy-benzoxazines $\mathbf{2 b - 6 b}$<smiles>[R]C([R])CN([CH])C1Oc2ccc(C(=O)O[CH]C)c3c2NC1([R])[R]3C</smiles>

$2 a-6 a$<smiles>[R]C1([R])Nc2c(ccc(C(=O)c3ccccc3)c2O)OC1O</smiles>

$2 b-6 b$

\begin{tabular}{|c|c|c|c|c|c|c|c|c|}
\hline Entry & Substrate & $\mathrm{R}^{1}, \mathrm{R}^{2}$ & Solvent & Acid (M) & Temp. $\left({ }^{\circ} \mathrm{C}\right)$ & Time & Product & Yield $(\%)^{b}$ \\
\hline 1 & $2 a$ & & $\mathrm{MeOH}$ & hydrochloric (0.1) & 60 & $30 \mathrm{~min}$ & $2 b$ & 95 \\
\hline 2 & $2 a$ & & $\mathrm{MeOH}$ & acetic (1.0) & 60 & $3.5 \mathrm{~h}$ & $2 b$ & 97 \\
\hline 3 & $2 a$ & $(\mathrm{Cl}$ & toluene & silica & 60 & $5.5 \mathrm{~h}$ & $2 b$ & 88 \\
\hline 4 & $2 a$ & & toluene & silica & 20 & $24 \mathrm{~h}$ & $2 b$ & 85 \\
\hline 5 & $3 a$ & & $\mathrm{MeOH}$ & hydrochloric $(0.1)$ & 60 & $30 \mathrm{~min}$ & $3 b$ & 97 \\
\hline 6 & $4 a$ & $\mathrm{Me}, \mathrm{Me}$ & $\mathrm{MeOH}$ & hydrochloric $(0.1)$ & 60 & $15 \mathrm{~min}$ & $4 b$ & 97 \\
\hline 7 & $4 a$ & $\mathrm{Me}, \mathrm{Me}$ & $\mathrm{MeOH}$ & acetic (1.0) & 60 & $30 \mathrm{~min}$ & $4 b$ & 96 \\
\hline 8 & $5 a$ & $\mathrm{Me}, \mathrm{Et}$ & $\mathrm{MeOH}$ & hydrochloric (0.1) & 60 & $20 \min$ & $5 b$ & 98 \\
\hline 9 & $6 a$ & $\mathrm{Ph}, \mathrm{Ph}$ & $\mathrm{MeOH}$ & hydrochloric $(0.1)$ & 60 & $24 \mathrm{~h}$ & $6 b$ & $60^{c}$ \\
\hline
\end{tabular}

${ }^{a}$ Reactions were carried out on a $2 \mathrm{mM}$ solution of substrate in solvent/acid (ca. 70/30 ratio).

${ }^{b}$ Yields refer to chromatographically pure isolated products. ${ }^{c} 30 \%$ of the recovered substrate were obtained also.

The progress of the electrolysis was simultaneously followed by monitoring the UV-vis absorption spectrum. After applying the potential $(E=+50 \mathrm{mV}$ vs $\mathrm{SCE})$, no spectral changes were observed for a time, consistent with steady state catalytic behavior (Figure 2). After the consumption of 5 faraday $(\mathrm{F}) \mathrm{mol}^{-1}$, a decrease in the $\mathrm{UV}$-vis absorption band shown by the monoanionic form of $\mathbf{1}_{\text {red }}$ at $350 \mathrm{~nm}\left(\varepsilon / \mathrm{mol}^{-1} \mathrm{~L} \mathrm{~cm}^{-1}=19000\right)$ was observed, while new bands at $320 \mathrm{~nm}$ and $259 \mathrm{~nm}$ developed. Spectral changes showed three isosbestic points at 330, 245 and $230 \mathrm{~nm}$, indicating that a simple equilibrium between two species was shifted. The new bands at 320 and $259 \mathrm{~nm}$ could be assigned to the 2-alkylamino-1,4-benzoxazine $\mathbf{2 a}$, as corroborated after recording the UV-vis absorption spectrum of the isolated product. 
QuickTime TM et un décompresseur
Photo - JPEG sont requis pour visualise

cette image.

Figure 2. Spectrophotometric changes accompanying the electrochemical oxidation of $1_{\text {red }}(2 \mathrm{mM})$ at a mercury pool $(\mathrm{E}=+50 \mathrm{mV}$ vs $\mathrm{SCE})$, in deaerated $\mathrm{MeOH}$ containing tetraethylammonium perchlorate $(20 \mathrm{mM})$ and aminomethylcyclohexane $(40 \mathrm{mM}$ ). Cell thickness, $0.1 \mathrm{~cm}$. (a) 0 (before electrolysis); (b) 6; (c) 10; (d) 12; (e) 16 moles of electrons.

Scope of the $1_{0 x}$-mediated cascade reactions. With the reliable set of conditions in hand, we probed the generality of the IEDDA reaction with a variety of electrogenerated enamines. Table 2 shows some examples of the molecular diversity that is accessible through this reaction which is an inverse-electrondemand controlled Diels-Alder reaction between the electron-poor $o$-azaquinone heterodiene and the electron-rich enamine dienophile. This uncatalyzed cycloaddition reaction occurs at room temperature, within $8-10 \mathrm{~h}$, with complete regiospecificity. The more electron-rich carbon atom of the enamine dienophile adds to the nitrogen atom of the heterodiene system $\mathbf{1}_{\mathbf{o x}}$ (Scheme 2). Accordingly, alkylenamines with a pronounced electron-rich character led to the formation of the expected 
cycloadduct in high yields (Table 2, entries 1-4), whereas the enamine that bore phenyl substituents resulted in somewhat lower yield (Table 2, entry 5).

Interestingly, when we used a cyclic alkylenamine generated from the $\mathbf{1}_{\mathbf{o x}}$-mediated catalytic oxidation of 2-methylcyclohexylamine, we found that the cascade sequence led to heterocyclic annulation in a diastereospecific manner, as established on the basis of NOE experiments (see Experimental Section). Nevertheless, the 5a-alkylamino-phenoxazine 7a was isolated in modest yield (25\%) for two reasons. First, it was easily hydrolyzed by silica gel to afford the hemiacetal by-product 7b in $15 \%$ yield (Table 2, entry 6). Second, the concomitant formation of the less substituted cyclic alkylenamine isomer, which could not be avoided, ${ }^{11}$ did not afford the corresponding phenoxazine derivative. This was supported by the attempt to react cyclohexylamine, where no product was formed.

In the specific case of ring-substituted phenylethylamines as the amine starting material, the catalytic process ceased rapidly (2-5 turnovers), while a yellow solid precipitated in the electrolysis solution. This was collected by filtration and identified as a 2-alkylamino-1,4-benzoxazine derivative. As described above, the electrogenerated 3,4-azaquinone $\mathbf{1}_{\mathbf{x}}$ was trapped through [4+2] cycloaddition with alkylenamines, leading to unstable aryl-2H-3,4-dihydro-1,4-benzoxazine intermediates (scheme 3,

Scheme 3 . $1_{\text {ox }}$-mediated cascade sequence leading to 2-alkylamino1,4-benzoxazine derivatives 8-14.

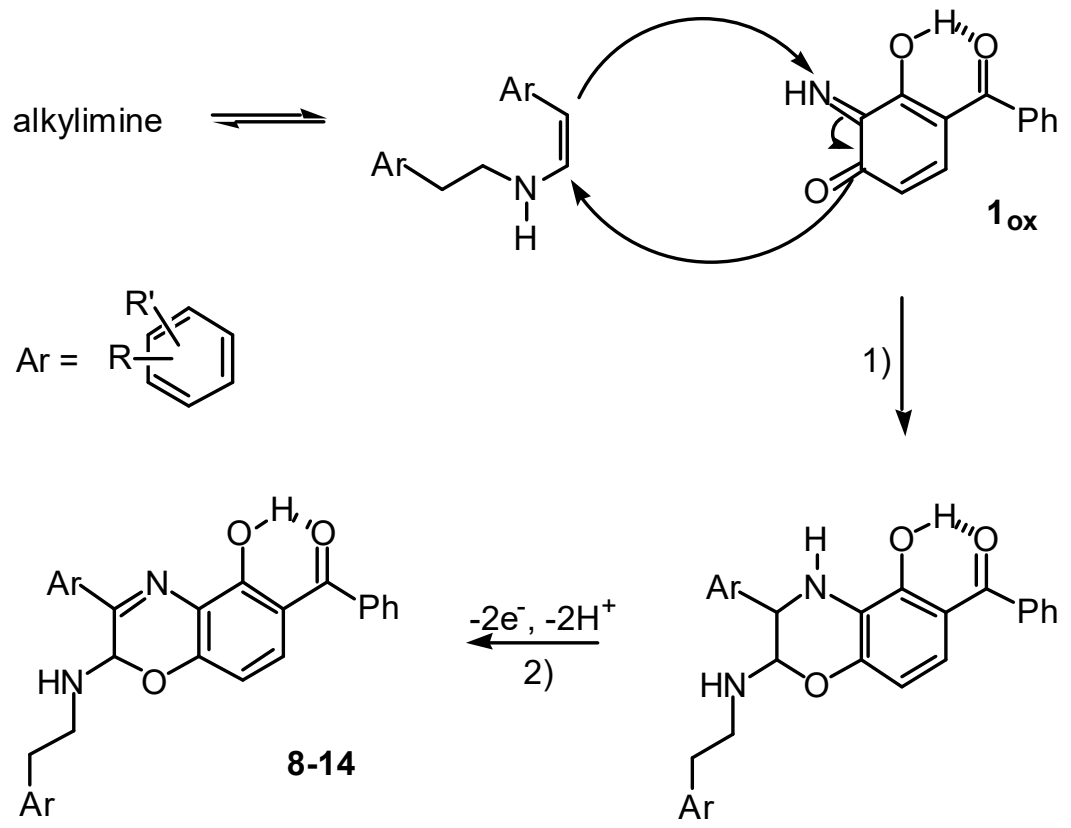


step 1). However, these compounds could be isolated as stable products 8-13 in yields ranging from 58 to $76 \%$ (Table 4, entries 1-6), after a subsequent two-electron oxidation step (Scheme 3, step 2). Note that the yield of the benzoxazine derivative $\mathbf{1 4}$ decreased to $20 \%$ when a methoxy group was introduced in ortho position of the phenyl ring, probably for steric reasons (Table 4, entry 7). 
Table 4. $1_{\text {ox }}$-mediated cascade sequence affording 2-alkylamino-1,4-benzoxazine derivatives8-14

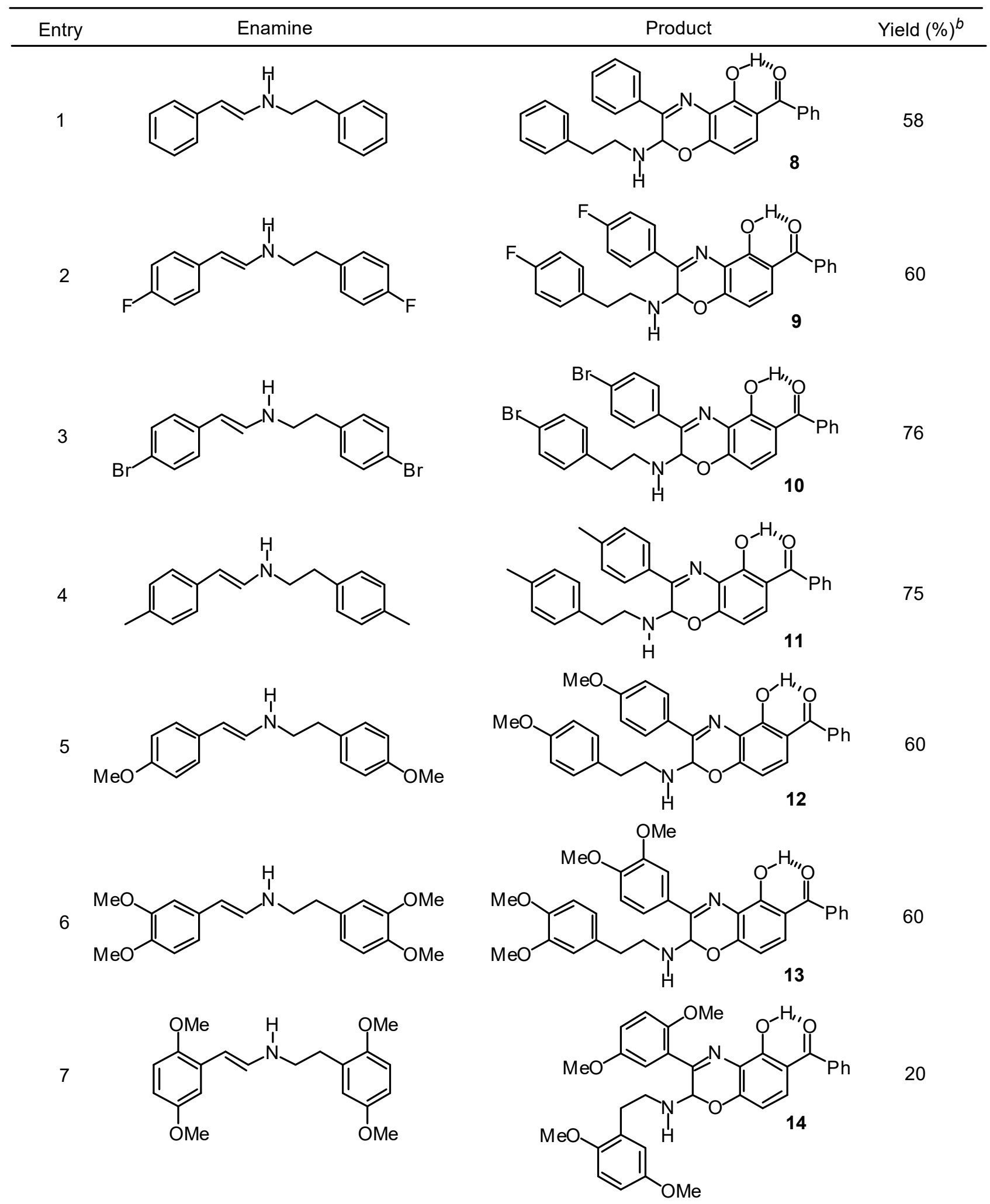

${ }^{a}$ Reagents and conditions : $\left(1_{\text {red }}\right)=2 \mathrm{mM},($ amine $)=40 \mathrm{mM}, \mathrm{MeOH}, \mathrm{rt}, \mathrm{Hg}$ anode $(\mathrm{E}=+50 \mathrm{mV}$ vs SCE$), 6-8 \mathrm{~h}$. ${ }^{b}$ Yields refer to chromatographically pure isolated products. 
All the above results showed that, under our experimental conditions, no subsequent elimination of the alkylamino chain was observed, in contrast to what has been previously reported for similar cycloaddition reactions of enamines with heterodienes. ${ }^{12}$ This feature is of synthetic interest since the multi-step one-pot electrochemical procedure we describe representes the first synthesis of 1,4benzoxazine derivatives that bear alkylamino substituents on the oxazine ring. ${ }^{13}$

\section{Catalytic oxidation of amine $\mathrm{R}^{1} \mathrm{R}^{2} \mathrm{CHCH} \mathrm{NH}_{2}$ mediated by the 3,4 -azaquinone $1_{\mathrm{ox}}$ in the presence}

of a second amine $\mathbf{R}^{3} \mathbf{N H}_{2}$. In a second series of experiments aimed at increasing the molecular diversity, we attempted to generate enamines in which the substituents on the amino group were different from those linked to the double bond. For this purpose, the amine $\mathrm{R}^{1} \mathrm{R}^{2} \mathrm{CHCH}_{2} \mathrm{NH}_{2}$ was catalytically oxidized by $o$-azaquinone $\mathbf{1}_{\mathbf{o x}}$ in the presence of a second primary aliphatic amine $\mathrm{R}^{3} \mathrm{NH}_{2}$. Table 5 gives some examples of 1,4-benzoxazine derivatives produced in this way. Efforts were made to optimize the yield of benzoxazines and led to the conclusion that the optimum conditions required roughly equimolar quantities of both reacting amines. However, the choice of amines proved to be important for the outcome of the reaction which was affected by steric and electronic effects exerted by the substituents $\mathrm{R}^{1}, \mathrm{R}^{2}$ and $\mathrm{R}^{3}$ : the most nucleophilic amine was oxidized, except when prevented by steric hindrance (Table 5, entries 1-8). Concerning the low yield of the 1,4-benzoxazine derivative 23 (Table 5, entry 9), it was due to the concomitant formation of another enamine which afforded the unwanted benzoxazine 6a (Table 2, entry 5) as the major product.

Another limitation of our electrochemical procedure that uses both in situ generated diene and dienophile was illustrated by the catalytic oxidation of a primary amine $\mathrm{R}^{1} \mathrm{R}^{2} \mathrm{CHCH}_{2} \mathrm{NH}_{2}$ mediated by the $o$-azaquinone $\mathbf{1}_{\mathbf{o x}}$ in the presence of a secondary amine $\mathrm{R}^{3} \mathrm{NHR}^{4}$, which failed to produce the expected tertiary alkylenamine, whereas the secondary alkylenamine continued to be generated leading to the benzoxazine derivatives reported in Table 2. Therefore, to avoid these limitations, we envisioned some modifications of the aforementioned procedure. 
Table 5. ${ }_{\text {ox }}$-mediated oxidation of amine $\mathrm{R}^{1} \mathrm{R}^{2} \mathrm{CHCH}_{2} \mathrm{NH}_{2}$, in the presence of a second amine $\mathrm{R}^{3} \mathrm{NH}_{2}{ }^{a}$

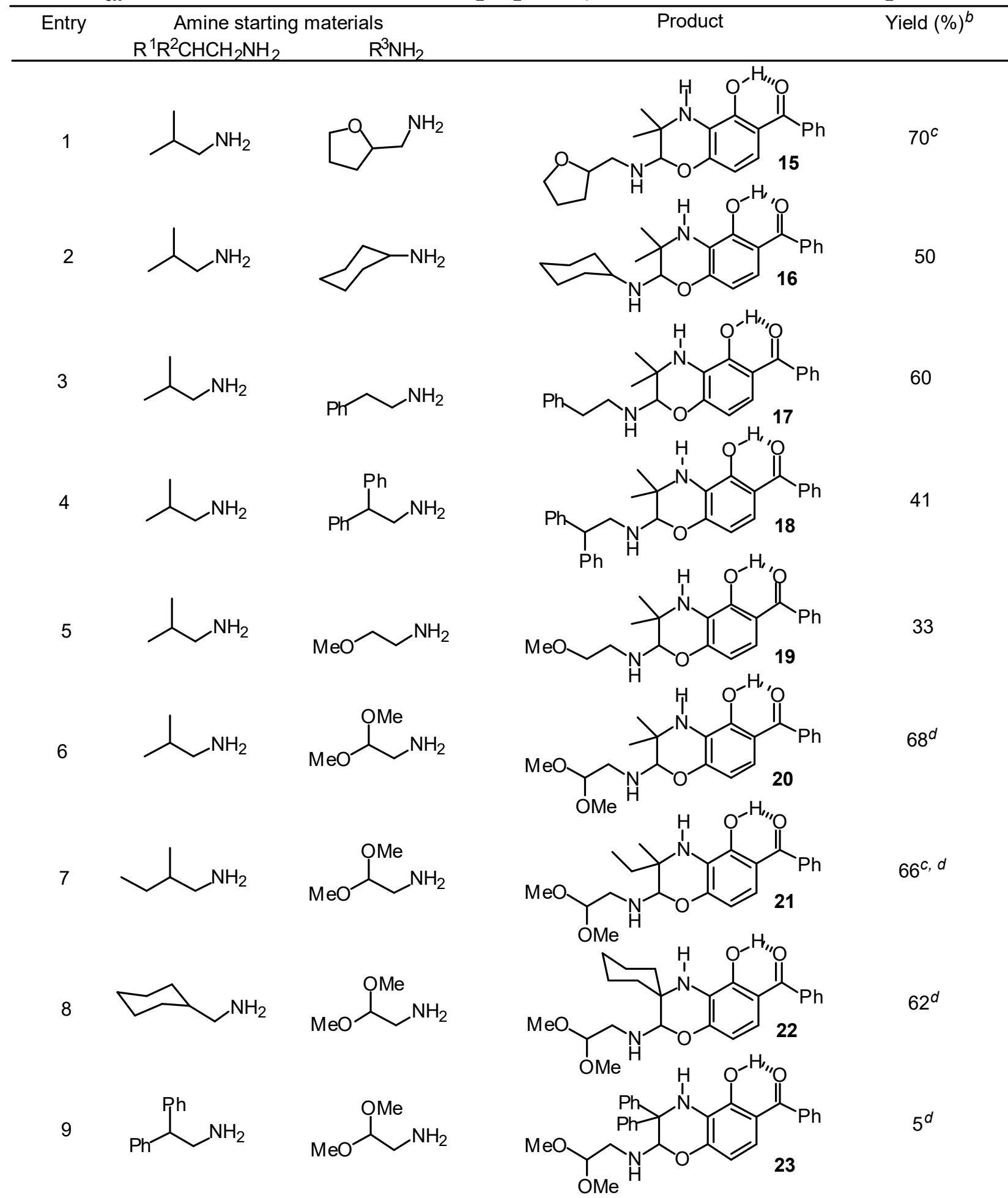

${ }^{a}$ Reagents and conditions : $\left(\mathbf{1}_{\text {red }}\right)=2 \mathrm{mM},\left(\mathrm{R}^{1} \mathrm{R}^{2} \mathrm{CHCH}_{2} \mathrm{NH}_{2}\right)=\left(\mathrm{R}^{3} \mathrm{NH}_{2}\right)=20 \mathrm{mM}, \mathrm{MeOH}, \mathrm{rt}, \mathrm{Hg}$ anode $(\mathrm{E}=+50 \mathrm{mV}$ vs SCE$), 8-10 \mathrm{~h} .{ }^{b}$ Yields refer to chromatographically pure isolated products. ${ }^{c}$ Obtained as a mixture of two unassigned diastereoisomers (ca. 1:1 ratio). ${ }^{d}$ Beside benzoxazines $\mathbf{2 0}, \mathbf{2 1}, \mathbf{2 2}$ and $\mathbf{2 3}$, benzoxazines $\mathbf{4 a}, \mathbf{5 a}, \mathbf{2 a}$ and $\mathbf{6 a}$ were isolated as by-products, in yields of 5, 10, 20 and $40 \%$, respectively, as a consequence of the concomitant production of another unwanted enamine. 


\section{Cycloaddition reaction of the electrogenerated azaquinone $1_{0 x}$ with a separately prepared}

enamine. To extend the scope of the reaction, we focused on the [4+2] cycloaddition of a separately prepared enamine with the electrogenerated 3,4-azaquinone $\mathbf{1}_{\mathbf{o x}}$. Thus, the cycloaddition would no longer be limited to the enamine part that originates from the more nucleophilic amine and it could be performed with tertiary alkylenamines. To explore this novel prospect, a series of secondary and tertiary enamines was synthesized by condensation of the appropriate aldehyde (or ketone) and amine. Then, their reactivity in IEDDA reactions with electrogenerated $o$-azaquinone $\mathbf{1}_{\mathbf{o x}}$ was examined. Our initial attempts to prepare the expected 2-alkylamino-1,4-benzoxazine derivatives were disappointing, leading to low yields of the desired products. We attributed these results to the instability of both 3,4azaquinone $\mathbf{1}_{\mathbf{o x}}$ and secondary enamines which prohibited their efficient use in IEDDA reactions. So, to circumvent this problem, compound $\mathbf{1}_{\text {red }}$ was added by small portions to the electrolysis solution, which contained the separately prepared enamine. In the meantime, the anodic potential was maintained at +50 $\mathrm{mV}$ vs SCE (See Experimental Section). Thus, the continuously low concentration of the electrogenerated $o$-azaquinone $\mathbf{1}_{\mathbf{o x}}$, together with the large excess of enamine, should promote the cycloaddition reaction at the expense of the dimerization, or polymerization, of both cycloaddition partners. As shown in Table 6 (entry 1), the reaction proved to be efficient since the yield of the benzoxazine derivative $\mathbf{2 3}$ was markedly improved (55\%), when compared to that of the aforementioned electrochemical procedure (5\%) (Table 5, entry 9). Similarly, the desired products $\mathbf{2 4 - 2 6}$ could be isolated within $4 \mathrm{~h}$, in yields ranging from 45 to $61 \%$ (Table 6, entries 2-4).

As confirmed by NMR experiments, condensation of 2-methylcyclohexanone and appropriate amine produced the corresponding imine, which tautomerized to enamine in the course of the anodic electrolysis, yielding two regiochemically distinct isomers. As already reported, the most substituted enamine and the electrogenerated $o$-azaquinone $\mathbf{1}_{\mathbf{0 x}}$ cyclized with complete diastereospecificity to give the 2-alkylamino-1,4-benzoxazine derivatives $\mathbf{2 7}$ and $\mathbf{2 8}$ in $25 \%$ yield (Table 6, entries 5 and 6). 
Table 6. $(4+2)$ cycloaddition reaction of the electrogeneratedo-azaquinone diene $\mathbf{1}_{\mathrm{ox}}$ and separately prepared enamine dienophile ${ }^{a}$

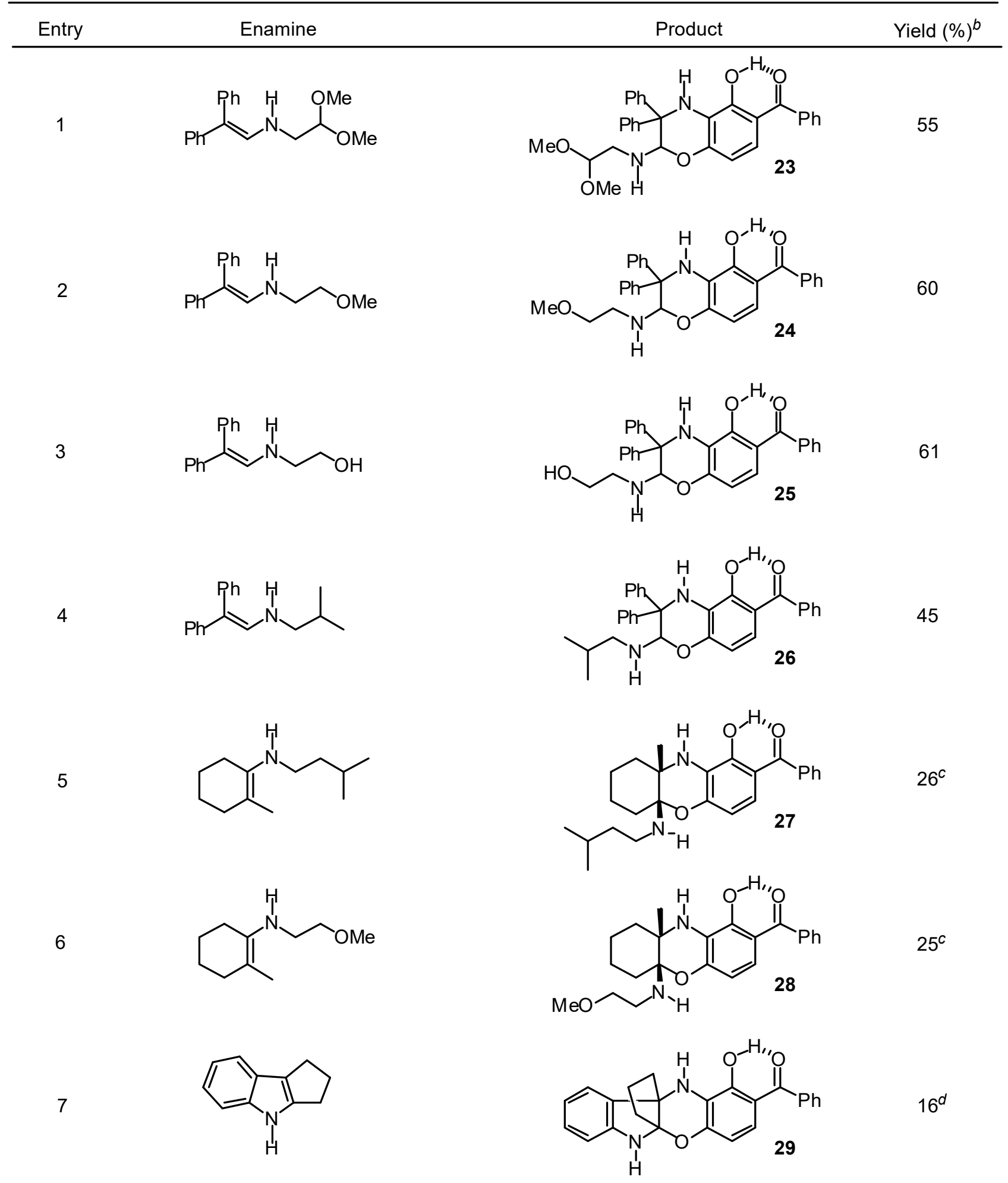


Table 6. (continued)

\begin{tabular}{|c|c|c|}
\hline Entry & Product & Yield $(\%)^{b}$ \\
\hline 8 & & 64 \\
\hline 9 & & 80 \\
\hline 10 & & 75 \\
\hline 11 & & 26 \\
\hline 12 & & 14 \\
\hline 13 & & 14 \\
\hline \multicolumn{3}{|c|}{$\begin{array}{l}{ }^{a} \text { Reagents and conditions : }\left(\mathbf{1}_{\mathrm{red}}\right)=2 \mathrm{mM} \text {, (enamine) }=6-10 \mathrm{mM}, \mathrm{MeOH}, \mathrm{rt}, \mathrm{Hg} \text { anode }(\mathrm{E}=+50 \mathrm{mV} \text { vs SCE}), 4 \mathrm{~h} ; 1 \text { equiv of } \\
\text { amine engaged in the synthesis of the enamine was added to the bulk solution for producing the monoanionic species of }{ }^{\mathbf{1}_{\text {red }} \text {, }} \\
\text { which is the sole form that can be oxidized to } \mathbf{1}_{\mathrm{ox}} \cdot{ }^{b} \text { Yields refer to chromatographically pure isolated products. }{ }^{c} \text { Beside } \\
\text { benzoxazines } \mathbf{2 7} \text { and } \mathbf{2 8} \text {, hemiacetal } \mathbf{7 b} \text { was isolated as by-product in roughly } 10 \% \text { yield. }{ }^{d} 1 \text { equiv of tert-butylamine was } \\
\text { added to the bulk solution for producing the monoanionic species of } \mathbf{1}_{\text {red. }}\end{array}$} \\
\hline
\end{tabular}


Despite its aromaticity, commercially available 2,3-dihydro- $1 H$-cyclopent[b]indole with latent enamine functionality participated in the IEDDA reaction with the electrogenerated $o$-azaquinone diene $\mathbf{1}_{\mathrm{ox}}$ affording the expected indolo-benzoxazine ring system 29 in $16 \%$ yield (Table 6 , entry 7 ). ${ }^{14}$

As for the secondary enamines (Table 2), tertiary alkylenamines with a pronounced electron-rich character led to the formation of the expected cycloadduct in high yields (Table 6, entries 8-10), whereas introduction of phenyl substituents resulted in lower yields (Table 6, entries 12 and 13). Surprisingly, with 1-piperidino-2-methyl-1-propene (Table 6, entry 11), the yield of the desired cycloadduct 33 was found to be low (26\%). This result presumably reflected the particular instability of the alkylenamine in the course of the anodic electrolysis.

\section{Conclusion}

In this article, we have described a cascade transformation traversing through an $o$-iminoquinone and demonstrated its synthetic utility for the construction of polyfunctionalized 1,4-benzoxazine derivatives. The reactions are regiospecific and diastereospecific in the case of heterocyclic annulation. The electrochemical procedure, wherein both cycloaddition partners are generated in situ, allows the systematic study of the IEDDA reaction of an $o$-iminoquinone and a secondary alkylenamine, two chemically non accessible unstable materials. ${ }^{11 b, 15}$ The methodology that uses a separately prepared secondary or tertiary enamine nicely completes the initial electrochemical procedure in terms of increasing the molecular diversity. Interestingly, the reactions can be conducted at room temperature, under metal-free conditions. The extension of this cascade reaction should be useful to generate libraries of heterocycles which constitute the molecular framework of medicinally relevant compounds. Finally, as a result of their structural similarity with a series of topologically different 1,4-benzoxazine derivatives reported earlier, ${ }^{16}$ the biological evaluation of these new benzoxazine derivatives as neuroprotective agents is currently in progress and will be reported elsewhere. 


\section{Experimental Section}

Chemicals were commercial products of the highest available purity and were used as supplied. Reduced catalyst $\mathbf{1}_{\text {red }}$ was synthesized as earlier reported. ${ }^{17}$ All apparatus, cells and electrodes were identical with those described previously. ${ }^{18}$

[(R,S)-2-cyclohexylmethylamino-5-hydroxy-3-spiro-1'-cyclohexyl-3,4-dihydro-2H-1,4-benzoxazin6-yl](phenyl)methanone 2a. 3,4-aminophenol $\mathbf{1}_{\text {red }}(114.5 \mathrm{mg}, 0.5 \mathrm{mmol})$ and aminomethylcyclohexane $(1.3 \mathrm{~mL}, 10 \mathrm{mmol})$ were added to a $0.02 \mathrm{M}$ solution of tetraethylammonium perchlorate (TEAP) (1.15 g, $5 \mathrm{mmol}$ ) as the supporting electrolyte in $\mathrm{MeOH}$. The resulting solution was then oxidized under nitrogen, at room temperature, at a mercury pool whose potential was fixed at $+50 \mathrm{mV}$ vs SCE (initial current $50 \mathrm{~mA})$. After exhaustive electrolysis $(8 \mathrm{~h}, \mathrm{n}=16)$, that is, when a negligible current was recorded $(1 \mathrm{~mA})$, the solution was neutralized with dry ice and the solvent was removed under reduced pressure. The brown oil residue was then poured into diethyl ether $(20 \mathrm{~mL})$. Insoluble TEAP was filtered off and the filtrate was evaporated under reduced pressure, at $30^{\circ} \mathrm{C}$. Flash chromatography of the residue on silica gel with toluene as the eluent afforded the expected 1,4-benzoxazine 2a in 77\% yield (167 mg, $0.385 \mathrm{mmol})$ as a yellow solid which was recrystallized from pentane/ether $(60 / 40), \mathrm{mp}: 129-131^{\circ} \mathrm{C} ;{ }^{1} \mathrm{H}$ NMR $\left(300 \mathrm{MHz}, \mathrm{CDCl}_{3}\right) \delta$ 0.85-1.80 (m, 21H), $1.95(\mathrm{~s}, 1 \mathrm{H}), 2.55(\mathrm{~m}, 1 \mathrm{H}), 2.75(\mathrm{~m}, 1 \mathrm{H}), 4.30(\mathrm{~s}, 1 \mathrm{H})$, $4.75(\mathrm{~s}, 1 \mathrm{H}), 6.35(\mathrm{~d}, J=9 \mathrm{~Hz}, 1 \mathrm{H}), 7.00(\mathrm{~d}, J=9 \mathrm{~Hz}, 1 \mathrm{H}), 7.50(\mathrm{~m}, 3 \mathrm{H}), 7.70(\mathrm{~d}, J=8 \mathrm{~Hz}, 2 \mathrm{H}), 12.75$ $(\mathrm{s}, 1 \mathrm{H}) ;{ }^{13} \mathrm{C} \mathrm{NMR}\left(75 \mathrm{MHz}, \mathrm{CDCl}_{3}\right) \delta 21.2,21.4,25.5,26.0,26.6,31.2,33.2,33.5,38.5,51.6,51.9$, $91.8,108.7,112.6,120.6,123.8,128.0,128.8,131.1,138.5,147.2,152.1,203.0$; MS DCI $m / z 435$ $\left(\mathrm{MH}^{+}\right)$. Anal. Calcd for $\mathrm{C}_{27} \mathrm{H}_{34} \mathrm{~N}_{2} \mathrm{O}_{3}$ : C, 74.65; H, 7.83; N, 6.45. Found: C, 74.56; H, 8.11; N, 6.42.

\section{[(5aR,9aS)-1,5a-dihydroxy-9a-methyl-6,7,8,9,9a,10-hexahydro-5aH-phenoxazin-2-}

yl](phenyl)methanone $7 \mathbf{b}$ : Isolated as a single diastereoisomer with cis configuration; yellow solid recrystallized in ether, $\mathrm{mp}=192-194^{\circ} \mathrm{C} .{ }^{1} \mathrm{H}$ NMR $\left(500 \mathrm{MHz}, \mathrm{CDCl}_{3}\right) \delta 1.40(\mathrm{~s}, 3 \mathrm{H}), 1.45-1.90(\mathrm{~m}, 7 \mathrm{H})$, $2.12(\mathrm{~d}, J=14.5 \mathrm{~Hz}, 1 \mathrm{H}), 3.54(\mathrm{~s}, 1 \mathrm{H}), 4.02(\mathrm{~s}, 1 \mathrm{H}), 6.43(\mathrm{~d}, J=9 \mathrm{~Hz}, 1 \mathrm{H}), 7.02(\mathrm{~d}, J=9 \mathrm{~Hz}, 1 \mathrm{H}), 7.50$ $(\mathrm{m}, 3 \mathrm{H}), 7.67(\mathrm{~d}, J=7 \mathrm{~Hz}, 2 \mathrm{H}), 12.72(\mathrm{~s}, 1 \mathrm{H}) ;{ }^{13} \mathrm{C} \mathrm{NMR}\left(100 \mathrm{MHz}, \mathrm{CDCl}_{3}\right) \delta 20.6,22.0,22.8,33.2$, 
$35.1,53.9,99.3,108.8,113.5,120.1,124.5,128.7,129.4,131.9,138.8,147.2,152.5,201.2$; MS DCI $m / z 340\left(\mathrm{MH}^{+}\right)$. Anal. Calcd for $\mathrm{C}_{20} \mathrm{H}_{21} \mathrm{NO}_{4}: \mathrm{C}, 70.79 ; \mathrm{H}, 6.19 ; \mathrm{N}, 4.13$. Found: $\mathrm{C}, 70.54 ; \mathrm{H}, 6.41 ; \mathrm{N}$, 4.14. The cis junction of the bicyclic system was established on the basis of NOE experiments (mixing time : $250 \mathrm{~ms})$ : a NOE effect was observed between the 9a-angular methyl substituent (1.40 ppm) and the 5a-hydroxy group (3.54 ppm). The stereochemical assignment was confirmed when the hemiacetal cycloadduct $7 \mathrm{~b}$ was exposed for $48 \mathrm{~h}$ in $\mathrm{CDCl}_{3}$; then, a cis-trans equilibrium occurred leading to a $2 / 3$ vs 1/3 mixture of diastereoisomers, as already reported for similar derivatives. ${ }^{19}$ The NOE effect was no more observed with the minor isomer : ${ }^{1} \mathrm{H}$ NMR $\left(500 \mathrm{MHz}, \mathrm{CDCl}_{3}\right) \delta 1.20(\mathrm{~s}, 3 \mathrm{H}), 1.45-2.12(\mathrm{~m}, 8 \mathrm{H})$, $4.23(\mathrm{~s}, 1 \mathrm{H}), 4.30(\mathrm{~s}, 1 \mathrm{H}), 6.45(\mathrm{~d}, J=9 \mathrm{~Hz}, 1 \mathrm{H}), 7.10(\mathrm{~d}, J=9 \mathrm{~Hz}, 1 \mathrm{H}), 7.50(\mathrm{~m}, 3 \mathrm{H}), 7.67(\mathrm{~d}, J=7 \mathrm{~Hz}$ 2H), $12.81(\mathrm{~s}, 1 \mathrm{H}) ;{ }^{13} \mathrm{C} \mathrm{NMR}\left(100 \mathrm{MHz}, \mathrm{CDCl}_{3}\right) \delta 20.6,22.0,22.9,30.8,35.6,53.9,99.8,109.4,113.6$, $120.7,125.8,128.7,129.4,132.0,138.7,148.1,153.3,201.2$.

[(R,S)-5-hydroxy-3-phenyl-2-phenylethylamino-2H-1,4-benzoxazin-6-yl](phenyl)methanone 8. 3,4aminophenol $\mathbf{1}_{\text {red }}(114.5 \mathrm{mg}, 0.5 \mathrm{mmol})$ and phenylethylamine $(1.3 \mathrm{~mL}, 10 \mathrm{mmol})$ were added to a $0.02 \mathrm{M}$ solution of TEAP $(1.15 \mathrm{~g}, 5 \mathrm{mmol})$ in $\mathrm{MeOH}$. The resulting solution was then oxidized under nitrogen, at room temperature, at a mercury pool whose potential was fixed at $+50 \mathrm{mV}$ vs SCE (initial current $45 \mathrm{~mA})$. After exhaustive electrolysis $(6 \mathrm{~h}, \mathrm{n}=10)$, the electrolysis solution was concentrated until the 1,4-benzoxazine derivative precipitates in full. Then, the yellow solid was collected by filtration, washed with small fractions of $\mathrm{MeOH}$, and dried in a vacuum desiccator. (130 mg, $0.29 \mathrm{mmol}, 58 \%$ yield) $\mathrm{mp}: 193-195^{\circ} \mathrm{C} ;{ }^{1} \mathrm{H}$ NMR $\left(300 \mathrm{MHz}, \mathrm{CDCl}_{3}\right) \delta 2.35(\mathrm{~m}, 1 \mathrm{H}), 2.85(\mathrm{~m}, 2 \mathrm{H}), 3.20(\mathrm{~m}, 1 \mathrm{H}), 3.28$ (m, 1H), $5.95(\mathrm{~d}, J=11 \mathrm{~Hz}, 1 \mathrm{H}), 6.58(\mathrm{~d}, J=9 \mathrm{~Hz}, 1 \mathrm{H}), 7.15(\mathrm{~d}, J=7 \mathrm{~Hz}, 2 \mathrm{H}), 7.25(\mathrm{~m}, 3 \mathrm{H}), 7.40-7.60$ $(\mathrm{m}, 7 \mathrm{H}), 7.70(\mathrm{~d}, J=7 \mathrm{~Hz}, 2 \mathrm{H}), 8.00(\mathrm{~d}, J=7 \mathrm{~Hz}, 2 \mathrm{H}), 13.10(\mathrm{~s}, 1 \mathrm{H}) ;{ }^{13} \mathrm{C} \mathrm{NMR}\left(75 \mathrm{MHz}, \mathrm{CDCl}_{3}\right) \delta$ $37.2,46.6,81.8,108.8,114.7,123.1,126.8,127.9,128.8,128.9,129.0,129.2,129.5,131.4,132.2$, 134.2, 135.6, 138.6, 139.7, 151.4, 155.4, 161.1, 200.9 ; MS DCI $m / z 449\left(\mathrm{MH}^{+}\right)$. Anal. Calcd for $\mathrm{C}_{29} \mathrm{H}_{24} \mathrm{~N}_{2} \mathrm{O}_{3}:$ C, 77.68; H, 5.36; N, 6.25. Found: C, 77.59; H, 5.46; N, 6.24. 


\section{[(R,S)-2-(2,2-dimethoxy)ethylamino-3,3-diphenyl-5-hydroxy-3,4-dihydro-2H-1,4-benzoxazin-6-}

yl](phenyl)methanone 23. Freshly distilled enamine (425 mg, $1.5 \mathrm{mmol}$ ) was dissolved in methanol $(250 \mathrm{~mL})$ that contained TEAP $(1.15 \mathrm{~g}, 5 \mathrm{mmol})$, along with 2,2-dimethoxyethylamine $(55 \mu \mathrm{L}, 0.5$ $\mathrm{mmol})$. The addition of the latter was necessary to produce the monoanionic species of $\mathbf{1}_{\text {red }}$, which was the sole form that can be oxidized to $o$-azaquinone $\mathbf{1}_{\mathbf{o x}}$. Then, 3,4-aminophenol $\mathbf{1}_{\text {red }}(114.5 \mathrm{mg}, 0.5$ mmol) was added by small portions $(22.9 \mathrm{mg}, 0.1 \mathrm{mmol})$ to the solution which was oxidized at a mercury pool whose potential was fixed at $+50 \mathrm{mV}$ vs SCE, under nitrogen, at room temperature. After exhaustive electrolysis $(4 h, n=2)$, the solvent was removed under reduced pressure. The brown oil residue was then poured into diethyl ether $(20 \mathrm{~mL})$. Insoluble TEAP was filtered off and the filtrate was evaporated under reduced pressure, at $30^{\circ} \mathrm{C}$. Flash chromatography of the residue on silica gel with toluene/acetone $98 / 2 \mathrm{v} / \mathrm{v}$ as the eluent afforded the expected 1,4-benzoxazine $\mathbf{2 3}$ in 55\% yield (140 $\mathrm{mg}$, $0.274 \mathrm{mmol})$ as a yellow solid which was recrystallized from ether, $\mathrm{mp}: 154-156^{\circ} \mathrm{C} ;{ }^{1} \mathrm{H}$ NMR $(300$ $\left.\mathrm{MHz}, \mathrm{CDCl}_{3}\right) \delta 2.45(\mathrm{~m}, 1 \mathrm{H}), 2.95(\mathrm{~m}, 2 \mathrm{H}), 3.30(\mathrm{~s}, 3 \mathrm{H}), 3.35(\mathrm{~s}, 1 \mathrm{H}), 4.30(\mathrm{t}, J=6 \mathrm{~Hz}, 1 \mathrm{H}), 5.20(\mathrm{~s}$, 1H), $5.80(\mathrm{~d}, J=11 \mathrm{~Hz}, 1 \mathrm{H}), 6.35(\mathrm{~d}, J=9 \mathrm{~Hz}, 1 \mathrm{H}), 6.95(\mathrm{~d}, J=9 \mathrm{~Hz}, 1 \mathrm{H}), 7.10-7.55(\mathrm{~m}, 13 \mathrm{H}), 7.70(\mathrm{~d}$, $J=8 \mathrm{~Hz}, 2 \mathrm{H}), 12.85(\mathrm{~s}, 1 \mathrm{H}) ;{ }^{13} \mathrm{C} \mathrm{NMR}\left(75 \mathrm{MHz}, \mathrm{CDCl}_{3}\right) \delta 46.9,53.4,54.0,62.3,89.4,104.1,108.7$, $112.7,120.7,124.5,126.6,126.8,127.0,128.0,128.1,128.3,128.8,131.2,138.3,143.0,144.1,147.0$ 152.3, 201.5 ; MS DCI $m / z 511\left(\mathrm{MH}^{+}\right)$. Anal. Calcd for $\mathrm{C}_{31} \mathrm{H}_{30} \mathrm{~N}_{2} \mathrm{O}_{5}$ : C, 72.94; $\mathrm{H}, 5.88 ; \mathrm{N}$, 5.49. Found: C, 72.87; H, 5.95; N, 5.47.

Acknowledgment. We thank the Servier Company for financial support of this research.

Supporting information available: General experimental methods, ${ }^{1} \mathrm{H} /{ }^{13} \mathrm{C}$ NMR and MS spectral data, $\mathrm{CHN}$ analyses and melting points for substituted benzoxazine derivatives $\mathbf{2 b - 7 a}, \mathbf{9 - 2 2}, \mathbf{2 4 - 3 5}$.

\section{References}

(1) For recent reviews see (a) Corey, E.J.; Guzman-Perez, A. Angew. Chem. Int. Ed. 1998, 37, 388. (b) Jorgensen, K.A., Angew. Chem. Int. Ed. 2000, 39, 3558. (c) Buonoro, P.; Olsen, J.-C.; Oh, T. 
Tetrahedron, 2001, 57, 6099. (d) Fringuelli, F.; Taticchi, A. The Diels-Alder reaction : selected practical methods: Wiley, New York, 2002. (e) Corey, E.J. Angew. Chem. Int. Ed. 2002, 41, 1650.

(2) (a) Allen, J.G.; Hentemann, M.F.; Danishefsky, S.J. J. Am. Chem. Soc. 2000, 122, 571. (b) Tietze, L.F.; Modi, A. Med. Res. Rev. 2000, 20, 304 and references therein. (c) Nicolaou, K.C.; Snyder, S.A.; Montagnon, T.; Vassilikogiannakis, G. Angew. Chem. Int. Ed. 2002, 41, 1668 and references therein. (d) Williams, R.M.; Cox, R.J. Acc. Chem. Res. 2003, 36, 127 and references therein.

(3) (a) Auclair, K.; Sutherland, A. ; Kennedy, J. ; Witter, D.J. ; Van der Heever, J.P. ; Hutchinson, C.R. ; Vederas, J.C. J. Am. Chem. Soc. 2000, 122, 11519. (b) Watanabe, K.; Mie, T.; Ichihara, A.; Oikawa, M.; Honma, H. J. Biol. Chem. 2000, 275, 38393. (c) Pohnert, G. Chem.Bio.Chem. 2001, 2, 873. (d) Stuhlmann, F.; Jäschke, A. J. Am. Chem. Soc. 2002, 124, 3238. (e) Ose, T.; Watanabe, K.; Mie, T.; Honma, M.; Watanabe, H.; Yao, M.; Oikawa, H.; Tanaka, I. Nature, 2003, 422, 185.

(4) For a recent review on biosynthetically catalyzed Diels-Alder reactions see (a) Stocking, E. M.; Williams, R.M. Angew. Chem. Int. Ed. 2003, 42, 3078 and references therein. See also (b) Oikawa, H.; Kobayashi, T.; Katayama, K.; Suzuki, Y.; Ichihara, A. J. Org. Chem. 1998, 63, 8748. (c) Johansson, M.; Köpcke, B.; Anke, H.; Sterner, O. Angew. Chem. Int. Ed. 2002, 41, 2158. (d) Zhang, X.; Deng, Q.; Yoo, S.H.; Houk, K.N. J. Org. Chem. 2002, 67, 9043.(e) Schlatterer, J.C.; Stuhlmann, F.; Jäschke, A. Chem.Bio.Chem. 2003, 4, 1089.

(5) For reviews see (a) Boger, D.L. Tetrahedron, 1983, 39, 2869. (b) Boger, D.L. J. Heterocyclic Chem. 1998, 35, 1003 and references therein. (c) Behforouz, M.; Ahmadian, M. Tetrahedron, 2000, 56, 5259. (d) Jayakuman, S.; Iskar, M.P.S.; Mahajan, M.P. Tetrahedron, 2002, 58, 379.

(6) (a) Largeron, M.; Fleury, M.-B. J. Org. Chem. 2000, 65, 8874. (b) Largeron, M.; Neudorffer, A.; Fleury, M.-B. Angew. Chem. Int. Ed. 2003, 42, 1026.

(7) Largeron, M.; Neudorffer, A.; Vuilhorgne, M.; Blattes, E.; Fleury, M.-B. Angew. Chem. Int. Ed. 2002, 41,824 . 
(8) (a) Heine, H.W.; Barchiesi, B.J.; Williams, E.A. J. Org. Chem. 1984, 49, 2560. (b) Heine, H.W.; La Porte, M.G.; Overbaugh, R.H.; Williams, E.A. Heterocycles, 1995, 40, 743 and references therein. (c) Nicolaou, K.C.; Zhong, Y.L.; Baran, P.S. Angew. Chem. Int. Ed. 2000, 39, 622. (d) Nicolaou, K.C.; Sugita, K.; Baran, P.S.; Zhong, Y.L. Angew. Chem. Int. Ed. 2001, 40, 207. (e) Nicolaou, K.C.; Baran, P.S.; Zhong, Y.L.; Sugita, K. J. Am. Chem. Soc. 2002, 124, 2212. (f) Nicolaou, K.C.; Sugita, K.; Baran, P.S.; Zhong, Y.L. J. Am. Chem. Soc. 2002, 124, 2221.

(9) (a) Nicolaides, D.N.; Awad, R.W.; Varella, E.A. J. Heterocyclic Chem. 1996, 33, 633. (b) Nicolaides, D.N.; Bezergiannidou-Balouctsi, C.; Awad, R.W.; Litinas, K.E.; Malanidou-Xenikaki, E.; Terzis, A.; Raptopoulou, C.P. J. Org. Chem. 1997, 62, 499 and references therein.

(10) For a similar behavior see: Juhl, K.; Jorgensen, K.A. Angew. Chem. Int. Ed. 2003, 42, 1498.

(11) The preparation of enamines from unsymmetrically ketones gives rise to the formation of two regiochemically distinct isomers whose the ratio depends on the relative reactivity of the two enamines. As a general rule, the more substituted the enamine, the slower it undergoes reaction. (a) Gurowitz, W.D. ; Joseph, M.A. J. Am. Chem. Soc. 1967, 3289. (b) Whitesell, J.K.; Whitesell, M.A. Synthesis, 1983, 517 and references therein.

(12) For examples see (a) Danishefsky, S.J.; Cavanaugh, R. J. J. Org. Chem. 1968, 33, 2959 and references therein. (b) South, M.S.; Terri, L.; Jakuboski, M.D.; Westmeyer, M.D.; Dukersherer, D.R. J. Org. Chem. 1996, 61, 8921. (c) Koyama, J.; Toyokuni, I.; Tagahara, K. Chem. Pharm. Bull. 1998, 46, 332. (d) Boruah, R.C.; Ahmed, S.; Sharma, U.; Sandhu, J.S. J. Org. Chem. 2000, 65, 922. (e) Jones, R.M.; Selenski, C.; Pettus, T.R.R. J. Org. Chem., 2002, 67, 6911. (f) Kozhevnikov, V.N.; Kozhevnikov, D.N.; Nikitina, T.V.; Rusinov, V.L.; Chupakhin, O.N.; Zabel, M.; König, B. J. Org. Chem. 2003, 68, 2882. (g) Soenen, D.R.; Zimpleman, J. M.; Boger, D.L. J. Org. Chem. 2003, 68, 3593. (h) Bodwell, G.J.; Hawco, K.M.; Satou, T. Synlett, 2003, 6, 879 and references therein.

(13) To the best of our knowledge, only two syntheses of 1,4-benzoxazine derivatives bearing either a 2imidazoline or a 3-aminomethyl substituent have been reported until now: (a) Touzeau, F.; Arrault, A.; 
Guillaumet, G.; Scalbert, E.; Pfeiffer, B.; Rettori, M.-C.; Renard, P.; Mérou, J.-Y. J. Med. Chem. 2003, 46, 1962 and references therein. (b) Banzatti, C.; Heidempergher, F.; Melloni, P. J. Heterocyclic Chem. 1983, 20, 259.

(14) Indole has often served as a dienophile, especially for intramolecular IEDDA reaction. For a review see (a) Lee, L.; Snyder, J.K. Adv. in Cycloaddit. 1999, 6, 119. For very close examples using indoles see (b) Omote, Y.; Tomotake, A.; Kashima, C. Tetrahedron Lett. 1984, 25, 2993. (c) Omote, Y.; Harada, K.; Tomotake, A.; Kashima, C. J. Heterocyclic Chem. 1984, 21, 1841. (d) Black, D. St C.; Craig, D.C.; Heine, H.W.; Kumar, N.; Williams, E.A. Tetrahedron Lett. 1987, 28, 6691.

(15) It is known that secondary alkylenamines are thermodynamically unstable at room temperature and that the imino form is the sole detectable species; see: B. De Jeso, J.-C. Pommier J. Chem. Soc. Chem. Commun. 1977, 565 and references therein.

(16) (a) Largeron, M.; Lockhart, B.; Pfeiffer, B.; Fleury, M.-B. J. Med. Chem. 1999, 42, 5043. (b) Largeron, M.; Mesples, P.; Gressens, P.; Cechelli, R.; Spedding, M.; Le Ridant, A.; Fleury, M.-B. Eur. J. Pharmacol. 2001, 424, 189.

(17) Larget, R.; Lockhart, B.; Pfeiffer, B.; Neudorffer, A.; Fleury, M.-B.; Largeron, M. Bioorg. Med. Chem. Lett. 1999, 9, 2929.

(18) Largeron, M.; Neudorffer, A.; Fleury, M.-B. J. Chem. Soc. Perkin Trans 2 1998, 2721.

(19) (a) Levine, S.G.; Gragg, C.; Bordner, J. J. Org. Chem. 1976, 41, 4026. (b) Herzig, C.; Gasteiger, J. Chem. Ber. 1981, 114, 2348. 
Table of Contents Graphic

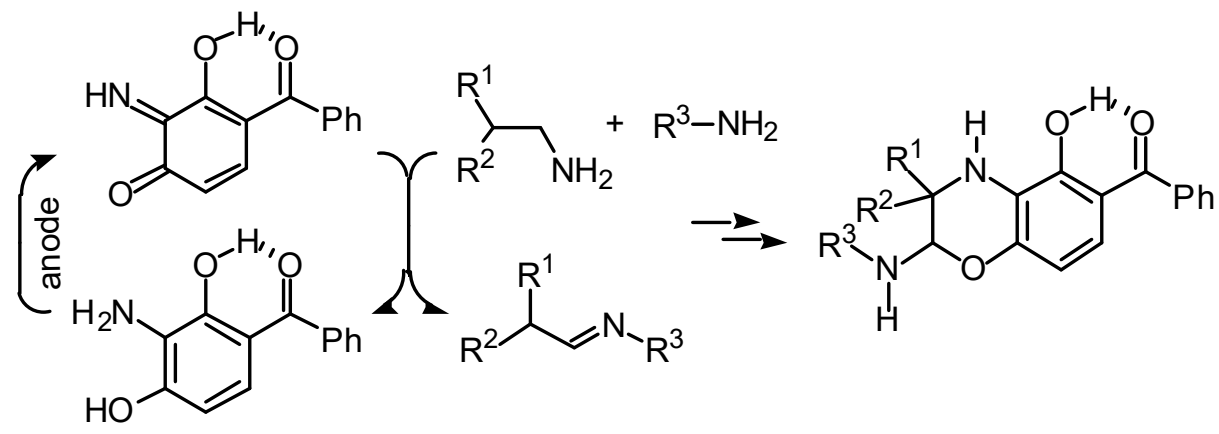

